Language and Language Teaching Journal http://e-journal.usd.ac.id/index.php/LLT Sanata Dharma University, Yogyakarta, Indonesia

\title{
THE ROLE OF STUDENTS' MOTIVATIONAL SELF-REGULATION IN STRUCTURE III
}

\author{
Thomas Wahyu Prabowo Mukti \\ Sanata Dharma University, Yogyakarta, Indonesia \\ thomaswpm@gmail.com
}

DOI: doi.org/10.24071/11t.2017.200205

received 4 June 2017; revised 10 July 2017; accepted 25 September 2017

\begin{abstract}
One of the important factors that influence the language learning, especially learning the basic rule of a language, is motivation. Many studies have tried to find out the correlation between motivation and self-regulation with the students' academic performance and they find out that both motivation and learning language are correlated so much. Thus, this paper specifically tried to find out the role of students' motivational self-regulation with the students' learning strategy. This research employed quantitative approach by employing survey method using observation sheet, questionnaire, and interview on some participants. The results of this study showed that the students' motivation was high but they cannot selfregulate themselves.
\end{abstract}

Keywords: motivation, motivational self-regulation, Structure III

\section{Introduction}

Nagy (1995) states that learning English as a foreign language is not the same as when people learn other subjects. It is not only a matter of learning vocabulary, structure, listening or speaking skills but also sociocultural. Language attitudes, cultural stereotypes, and even geopolitical considerations are the sociocultural factors that affect the second language learning (Gardner \& Lambert, 1972). Further, Nagy (1995) considers that learning a foreign language involves more than only the language skills but it also requires the learners to adapt to the culture of the language itself.

Considering the fact that learning language is not the same as learning other subjects, language learning requires motivation and self-regulation in the learning process in order to be successful in mastering the language. Gardner (2007) ponders that motivation can play an important role in learning a second language. Further, Gilakjani, Leon, and Sabouri (2012) even consider "motivation as the heart of learning and teaching activities" in the class (p. 9). By having the motivation to learn a language, the students will be able to self-regulate themselves since based on Lett and O'Mara (1990) and Gardner (2000), one of the most influential factors that affect students' self-regulation is their motivation. Students will be able to manage and control their effort on the classroom academic tasks (Pintrich \& De Groot, 1990, p. 33). Moreover, students will be 
able to maintain their cognitive engagement in the task that makes them be able to perform better (Zimmerman \& Pons, 1988, p. 8).

However, students' motivation is often neglected by teachers (Gilakjani, Leong \& Sabouri, 2012, p. 9). They add that teachers often forget that all of the learning activities success depends on the students' motivation. In this sense, students control the flow of the classroom. They consider that without students' motivation, there is no spirit for learning in the class. Similarly, Dornyei (2005) identifies that teachers may do not realize that even prodigies cannot accomplish long-term goals without motivation.

Teachers nowadays should consider that motivation, especially selfmotivation, is important in learning English. In addition, they have to be able to notice that motivation is continuously changing because of a variety of internal and external forces (Dornyei, 2001). Thus, it becomes clear that the internal monitoring, filtering, and processing mechanisms that learners employ in this dynamic process will have an important role in shaping the motivational outcome (Dornyei, 2005, p. 65). Besides, there are three components of motivation that should be considered, namely an expectancy component, which includes students' beliefs about their ability to perform tasks, a value component, which includes students' goals and beliefs about the importance and interest of the task, and an affective component, which includes students' emotional reactions to the task (Eccles, 1983; Pintrich, 1989).

Motivation is needed by EFL students who learn grammar because it is considered as one of the most important components in learning a language. Grammar is the structural foundation of learning a language (Zhang, 2009; Wang, 2010; Subasini \& Kokilavani, 2013). Further, Wang (2010) considers that with a good knowledge of grammar, students can improve their English proficiency. Nevertheless, grammar is considered as a powerful undermining and demotivating force among L2 learners. Students perceive that grammar is a problem and they are difficult to relate grammar to their lives (Nawaz et al., 2015, p. 2).

The conditions may make the students lose their motivation in learning English. The students may feel less interested in learning grammar so that it affects their academic performance. This condition may also affect the way students learn and it will also affect their achievement. Therefore, this study tries to propose the role of students' motivation self-regulation that closely relates to students' self-regulated learning in academic performance in a Structure III class. Based on the research background above, this study addresses one research question: What are the roles of students' motivational self-regulation in students' learning strategy in Structure III class?

\section{Motivation}

Motivation is something that prompts, incites or stimulates action. Motivation leads to the initial stages of an action (Gilakjani, Leong \& Sabouri, 2012, p. 9). It means motivation is related to the arousing initial interest and turning it into a decision to engage in some activity. The need to maintain this state of arousal, to determine someone to make the necessary effort to complete an action is also of great importance (Gilakjani, Leong \& Sabouri, 2012, p.9). Furthermore, Williams \& Burden, (1997) see motivation as a state of cognitive 
and emotional arousal that leads to a conscious decision to act and keep intellectual and/or physical effort. Similarly, Gardner (1985) sees motivation is a combination of effort plus desire to achieve a goal plus favorable attitudes towards the goal to be accomplished. In short, motivation is something that stimulates people to act for the goals they set and keep the effort for reaching the goals.

Pintrich and De Groot (1990, p. 33) propose a model that pictures students' motivational components that may be linked to the three different components of self-regulated learning. The components are (a) an expectancy component, which includes students' beliefs about their ability to perform task, (b) a value component, which includes students' goals and beliefs about the importance and interest of the task, and (c) an affective component, which includes students' emotional reactions to the task. Those three components will be discussed below.

First, the expectancy components are linked to students' metacognition, their use of cognitive strategies, and their effort management (Pintrich \& De Groot, 1990, p. 34). Some studies suggest that students who believe they have capability of learning languages and performing tasks will engage in more metacognition, use more cognitive strategies, and are more likely to do a task better than students who do not believe they can perform the task (Fincham \& Cain, 1986; Paris \& Oka, 1986; Schunk, 1985 as cited in Pintrich \& De Groot, 1990).

Second, the value component of student motivation involves students' goals for the task and their beliefs about the importance and interest of the task (Pintrich \& De Groot, 1990, p. 34). This motivational component is related to students' reasons for doing a task. The research suggests that motivated students who understand the importance of the activity they do will engage in more "metacognitive activity, cognitive strategy use, and effective effort management" (Pintrich \& De Groot, 1990, p.35).

Third, affective component is related to the students' affective or emotional reactions to the task (Pintrich \& De Groot, 1990, p.35). There is a variety of affective reactions that might be relevant to the affective components the most important in the school context is the students' anxiety (Wigfield \& Eccles, 1989) while the anxiety itself is linked to "students' metacognition, cognitive strategy use, and effort management” (Pintrich \& De Groot, 1990, p.35).

In summary, the writer would like to emphasize three components of motivation affect students' academic performance. The components are expectancy component, value component, and affective component. Those motivational components were linked in important ways to student cognitive engagement and academic performance in the classroom (Pintrich \& De Groot, 1990).

\section{Self-Regulated Learning}

Self-regulated learning is a process that assists students in managing their thoughts, behaviors, and emotions in order to successfully navigate their learning experiences (Zumbrunn, Tadlock \& Roberts, 2011). This process occurs when student's purposeful actions and processes are directed towards the acquisition of information or skills. Zimmerman (1990) states that self-regulated learners face 
the tasks in the school with confidence, diligence, and resourcefulness. He also emphasized that self-regulated learners are aware when they know a fact or possess a skill and when they do not.

Further, self-regulation is considered to be an important aspect of student learning and academic performance (Corno \& Mandinach, 1983). Pintrich and De Groot (1990) consider that there are three components related to students' classroom performance. First, self-regulated learning includes students' metacognitive strategies for "planning, monitoring, and modifying their cognition" (Boekaerts \& Corno, 2005, p.207). Second, self-regulated learning also includes students' management and control of their effort on classroom academic tasks. It focuses on how students are able to do a difficult task or block out distractors in order to maintain their cognitive engagement in the task that makes them enable to perform better (Corno, 1986; Corno \& Rohrkemper, 1985 as cited in Pintrich \& De Groot, 1990). Third, self-regulated learning also relates to the actual cognitive strategies that students use to learn, remember, and understand the material (Pintrich \& De Groot, 1990). Different cognitive strategies will help foster active engagement in learning and it will help students reach higher levels of achievement (Pintrich \& De Groot, 1990).

\section{Motivational Self-Regulation}

Related to the motivation and self-regulated learning, Dornyei (2005) highlights the importance of learner self-regulation by integrating the learners' proactive involvement in controlling the various aspects of their learning. He also underlines that self-regulation also includes motivation as one of the most important components. Thus, he defines the correlation of motivation and selfregulation as the motivational self-regulation. The focus of the motivational selfregulation is on "the 'whole' person and how they control their own motivation, emotions, behavior (including choice, effort, and persistence), and their environment, has been a welcome addition to research on academic selfregulation" (Dornyei, 2005, p.91). It means that students' self-regulation and motivation are interdependent and they affect students' academic performance.

It is assumed that students who have motivational self-regulation are able to maintain their motivation and keep themselves on task and they are expected to learn better than students who are less skilled at regulating their motivation. It can be understood since learning is the effortful process with a lot of obstacles may interfere students' initial motivation. Therefore, students' ability to keep in control with what they are doing or their goals should be considered as an important indicator for self-regulated learning (Wolters, 2003). In addition, Ushioda (2003) argued that the function of motivational self-regulation is to help learners to adapt motivational belief systems and engage in constructive and effective thinking to regulate their motivation. It means that by having motivational self-regulation, students will be able to maintain their motivation so they will engage in the task and reach their goals.

In summary, the motivational self-regulation plays important role in students' academic performance. By having the motivational self-regulation, students will be able to maintain their motivation to reach their goals. They also 
will be able to find the cognitive strategy that will help them to analyze their learning and understanding the right method for their learning.

\section{Method}

This research employed quantitative methods in order to collect and analyze the data. Specifically, it is survey research. Surveys enable the researcher to find out the major attitudes and opinions of a group of people toward some issue (Ary, Jacobs, Sorensen, Razavieh, 2010, p. 351). There were three steps the writer employed to conduct this research.

First, the writer observed one of Structure III classes in English Language Education Study Program. In this observation, observation sheet was used for generating the general knowledge of the students' motivation (Ary, Jacobs, Sorensen, Razavieh, 2010, p. 351). The focus of this observation is to observe students' attitudes directly in the class.

Second, after observing the class, the writer distributed questionnaires to all students who attended the class. The questionnaire consisted of fifteen statements related to the factors that make them motivated to learn, the strategy(s) to learn and how they manage their effort in learning. Further, the questionnaire also helped the writer to assess the students' attitudes toward Structure III class by presenting a set of statements related to their attitudes and their strategy they employed in Structure III class. (Ary, Jacobs, Sorensen, Razavieh, 2010, p. 351).

Third, the writer interviewed four participants in order to know the motivation of the participants and the way they regulate their effort, emotion, and strategy to learn. The writer recorded the data into transcripts. The data from the interviews were analyzed by using Creswell's (2009) qualitative data analysis by using QDA Miner ${ }^{\circledR}$. They were organizing and preparing the data for analysis, reading all the data, coding, representing the data in qualitative narrations, using the coding to generate categories or themes for analysis, and interpreting the data.

\section{Findings and Discussion}

In this subchapter, the writer will combine the results of the observation, questionnaires, and interviews. Here are the analyses of the findings:

\section{The Role of the Students' Motivational Self-Regulation on the Students' Academic Achievement}

In this chapter, the writer would like to elaborate the students' attitude, selfregulation, the motivational self-regulation and how those factors affect the students learning.

\section{Students' Attitude in Structure III}

Gilakjani, Leong \& Sabouri (2012) state that motivation is related to the arousing initial interest and turning it into a decision to engage in some activity ( $p$. 9). Gilakjani, Leong \& Sabouri (2012, p. 10) and that the need to maintain this state will determine someone's effort to complete an action. It means that students who have motivation can be observed from their actions and attitudes in the class. In order to know the students' attitude that also determines their motivation in the 
class, the writer employed observation sheet, questionnaire and interview guideline.

The students' attitude in the class was good. It can be observed from the observation (please refer to appendix 1) that I did on 16 November 2016. Most students show their enthusiasm by doing every task in the class, answering lecturer's questions, paying attention to their lecturer's explanation, asking questions when they do not understand the lecturer's explanation.

However, it should be noted that not all students showed their enthusiasm in the class. The writer found that some students were sleeping in the class, some students did not participate in the class activities and answer the lecturer's questions. Moreover, from the questionnaire statement number 11 which is "I always feel motivated in learning grammar both in the class and in my house/boarding house", only $34 \%$ students felt motivated in learning in the structure III class.

In summary, the students' attitude in Structure III class was good. It can be seen from the observation results that show students were quite enthusiastic in following the class activities. However, some students did not have the same enthusiasm as other students. To conclude, more than $80 \%$ students were enthusiastic in following the class activities which indicates that students were motivated in learning Structure III, a subject that considered to be the hardest subject by them.

\section{Students' Motivation and Motivational Self-Regulation in Structure III}

The components proposed by Pintrich and De Groot (1990, p. 33) to indicates the students" motivation in learning in the class. They are (a) an expectancy component, which includes students' beliefs about their ability to perform task, (b) a value component, which includes students' goals and beliefs about the importance and interest of the task, and (c) an affective component, which includes students' emotional reactions to the task. Those three components will be discussed below.

First, students showed that they believe in themselves that they are capable of passing the structure III class. Through the questionnaire, as can be seen in Figure 1, I discovered that $44 \%$ students believe that they will be able to get an A in the class while $22 \%$ students do believe that they will get an A. 


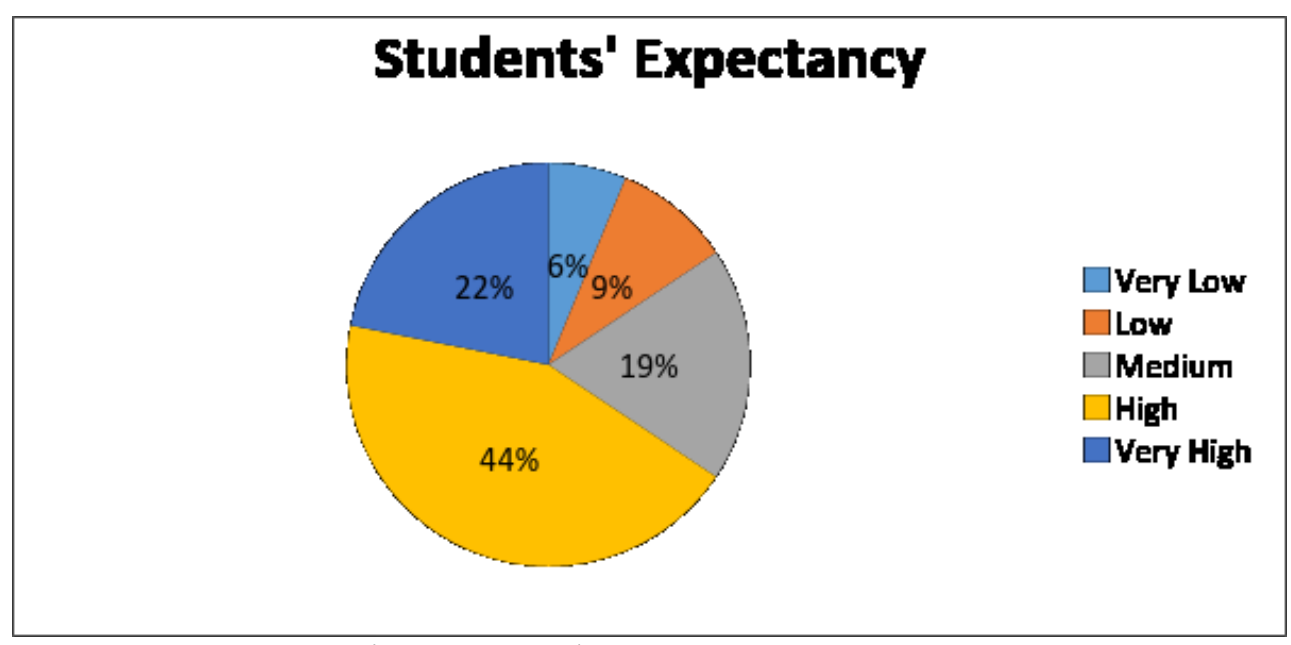

Figure 1. Students' Expectancy

Furthermore, the data from interviews also indicate that students have high expectancy. RDI state, "Kalau berdasarkan lihat nilai-nilai kemarin, kayae bisa dapat A (If I consider my previous scores, I think I can get an A)." However, MD, DTA and GPA stated that they only expect a B and they felt that they were pleased with it. From the fact above, the writer concludes that actually, students believe in themselves but they do not expect an A as their final score. They believe in their effort and the expectancy is mostly influenced by their quizzes and midterm test scores.

Second, the results of the questionnaire and interview show that students have their own reasons for doing the task (Pintrich \& De Groot, 1990, p.34). Based on the statements number three and four ("I learn English because I like the language and the culture" and "I learn English because I believe that English will be beneficial for my future"), the writer found that students actually have their own goal in learning structure III. The data can be seen on the next page:

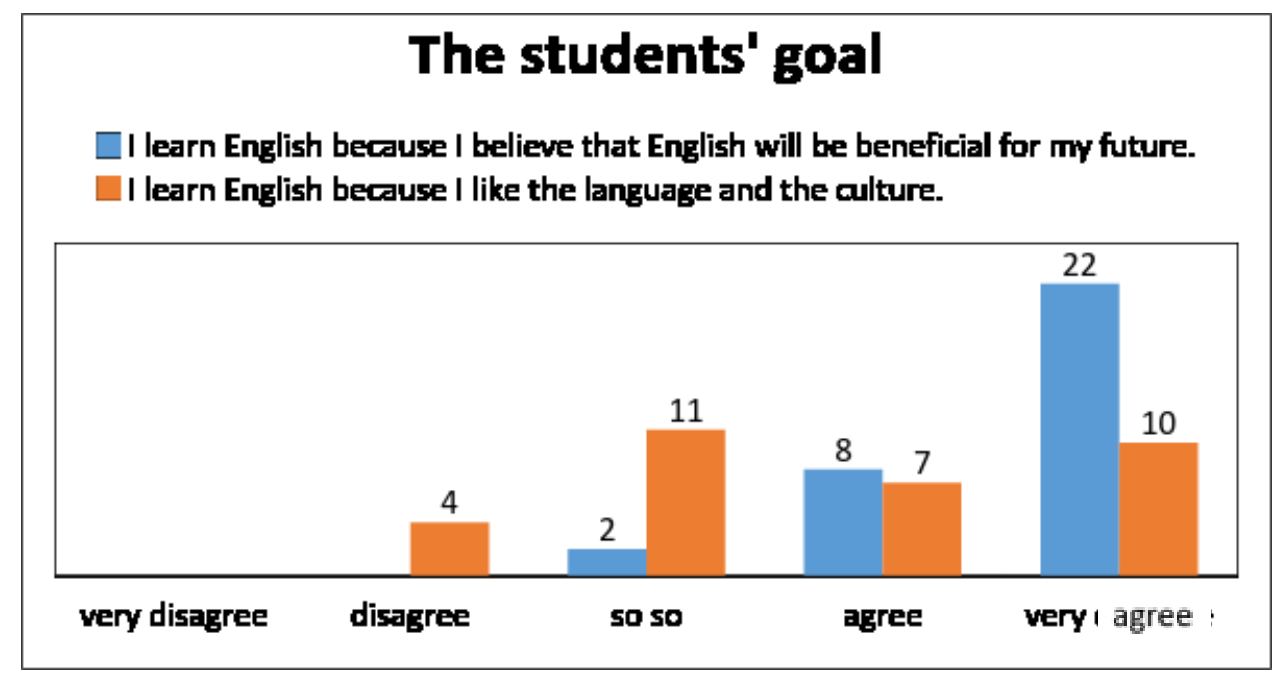

Figure 2. Students' Goal 
Based on the data from the questionnaire, it can be concluded that most students have their own goal in learning structure III. It may vary from the personal growth (statement number 2) until the functional use (statement number 3) but most students learn grammar for the functional use. In addition, the interview results strengthen the students' goal on the functional use. MD states, "Iya. Karena kita mungkin ngajar di SMP SMA kan? SMP itu tenses sudah belajar, terus kalimat aktif pasif juga udah. Terus di sini kita juga ngulang disitu tapi lebih dalam konteksnya. (Yes. We will teach in junior or senior high school, right?. In junior high school, they have learned tenses, active and passive sentence. We learn here but in deeper context)" when she was asked whether she will be a teacher or not in the future. In summary, the students' reasons in learning grammar were mostly about the functional use since someday they will be teachers thus they believe that they need to master grammar.

Third, it is related to the students' affection in doing tasks and/or tests. There is a variety of affective reactions that might be relevant to the affective components the most important in the school context is the students' anxiety (Wigfield \& Eccles, 1989). MD and GPA stated that they felt that they were not really enthusiastic about doing tasks or preparing for the tests. However, RDA states, "Aku tu malah nunggu-nunggu saat tes tu lho mas.kaya aku tu bener-bener kaya fell in love sama structure (I am actually waiting for the test. I think I fell in love with structure.)." Moreover, DTA stated that she was afraid of doing the test. She was afraid of making mistakes that actually led her to make mistakes. In brief, students' affections were different one to another in doing tasks and/or tests and it was reflected through the way students prepare and do the tasks and/or tests.

From those explanations about the students' motivation, the writer could also relate it to the self-regulated learning and motivational self-regulation. First, the students' motivation leads students to have the strategies for planning, monitoring, and modifying their cognition (Zimmerman \& Pons, 1988). It can be seen from the students' learning strategy to prepare quizzes or tests. From the questionnaire data, 78\% students agree that learning grammar is hard, so they need a strategy(s) in order to understand it (questionnaire statement number 6). It means that students are aware and they should have a strategy to learn. It also shows that they are motivated to learn.

However, students did not have their own schedule to learn grammar. It was only $16 \%$ of the students who had the strategy to learn grammar. Moreover, from the interview, all of the participants only learned before they have quizzes or tests. It means that students had the motivation but they did not manage themselves to learn more and have a better strategy.

Second, the students' motivation makes students able to manage and control their effort on classroom academic tasks (Pintrich and De Groot, 1990). From the observation, the writer could observe that some students tried to always listen to their lecturer. Though, some students did not pay attention to their lecturer. Some even slept in the class. MD and DTA admitted that they were sleepy in the class. GPA even underlined that the lecturers' method in teaching grammar is monotone and it demotivated him. It means that students did not really put their effort into learning in the class although they are motivated in learning grammar. 
In summary, after considering the students' attitude, motivation and the way they self-regulate themselves, the writer could conclude that students have a high motivation in learning grammar but some students could not really self-regulate themselves both their learning strategy and motivation. They know that they needed to learn harder on structure III but they did not manage themselves to learn more and have a better strategy to learn. As stated by Dornyei $(2005$, p. 91), the focus of the motivational self-regulation is on the 'whole' person and how they control their own motivation, emotions, behavior (including choice, effort, and persistence), and their environment. Some students could not manage their motivation into action that affects their way of learning. Therefore, students still need to manage their effort and persistence in learning grammar.

\section{Conclusion}

In conclusion, the writer concludes that students' motivation in learning grammar is high. However, they were demotivated for many factors and they also could not manage their motivation into action. In addition, some students were still not able to regulate their learning and motivation. Those factors affect the students' learning strategy. For the lecturers who teach Structure or Grammar class, they should consider the factors that make student motivated and demotivated, how to manage the students' motivation into action and how to help students regulate their motivation and learning strategy.

\section{References}

Ary, D., Jacobs, L. C., Sorensen, C., \& Razavieh, A. (2010). Introduction to research in education. Wadsworth: Cengage Learning.

Al Kaboody, M. (2013). Second language motivation: The role of teachers in learners' motivation. Journal of Academic and Applied Studies, 3(4), 45-54.

Al-Mekhlafi, A. M., \& Nagaratnam, R. P. (2011). Difficulties in teaching and learning grammar in an EFL context. Online Submission, 4(2), 69-92.

Boekaerts, M., \& Corno, L. (2005). Self-regulation in the classroom: A perspective on assessment and intervention. Applied Psychology, 54(2), 199-231.

Buckledee, S. (2008). Motivation and second language acquisition. ELOPE: English Language Overseas Perspectives and Enquiries, 5(1-2), 159-170.

Corno, L. (1986). The metacognitive control components of self-regulated learning. Contemporary educational psychology, 11(4), 333-346.

Corno, L., \& Mandinach, E. (1983). The role of cognitive engagement in classroom learning and motivation. Educational Psychologist, 18, 88-100.

Corno, L., \& Rohrkemper, M. (1985). The intrinsic motivation to learn in classrooms. Research on motivation in education, 2, 53-90.

Dörnyei, Z. (2001). Motivational strategies in the language classroom. Singapore: Cambridge University Press.

Dornyei, Z. (2005). The psychology of language learners: Individual differences in second language acquisition. New Jersey: Lawrence Erlbaum Associates, Inc., Publishers. 
Dörnyei, Z. (2007). Research methods in applied linguistics: Quantitative, qualitative, and mixed methodologies. Oxford: Oxford University Press.

Eccles, J. (1983). Expectancies, values and academic behaviors. In J. T. Spence (Ed.), Achievement and achievement motives: Psychological and sociological approaches (pp. 75-146). San Francisco, CA: Free man.

Engin, A. O. (2009). Second language learning success and motivation. Social Behavior and Personality: An International Journal, 37(8), 1035-1041.

Fincham, F. D., \& Cain, K. M. (1986). Learned helplessness in humans: A developmental analysis. Developmental Review, 6(4), 301-333.

Gardner, R.C. (2007). Motivation and second language acquisition. Porta Linguarum, 8, 9-20.

Gilakjani, A. P., Leong, L. M., \& Sabouri, N. B. (2012). A study on the role of motivation in foreign language learning and teaching. I.J.Modern Education and Computer Science, 7, 9-16.

Lett Jr, J. A., \& O'Mara, F. E. Predictors of Success in an Intensive Foreign Language Learning Context. Document Resume, 228.

Nagy, W. E. (1995). On the role of context in first-and second-language vocabulary learning. Champaign, Ill.: University of Illinois at UrbanaChampaign, Center for the Study of Reading.

Nawaz, H., Amin, M., \& Tatla, I. A. (2015). Factors Affecting Students' Motivation Level to Learn English as a Second Language in the Pakistani University Context. Journal of Research \& Reflections in Education (JRRE), 9(2).

Paris, S. G., \& Oka, E. R. (1986). Children's reading strategies, metacognition, and motivation. Developmental review, 6(1), 25-56.

Pintrich, P. R. (1989). The dynamic interplay of student motivation and cognition in the college classroom. Advances in motivation and achievement, 6, 117160.

Pintrich, P.R \& De Groot, E. V. (1990). Motivational and self-regulated learning components of classroom academic performance. Journal of Educational Psychology. 82(1). 33-40.

Root, E. (1999). Motivation and learning strategies in a foreign language setting: A look at a learner of Korean. Minneapolis, MN: Center for Advanced Research on Language Acquisition.

Schunk, D. H. (1985). Participation in goal setting: Effects on self-efficacy and skills of learning-disabled children. The Journal of Special Education, 19(3), 307-317.

Stefánsson, E. G. (2013). Second language acquisition: Mine the effect of age and motivation. Unpublished Thesis: Universitatis Islandiae Sigillum, Reykjavic.

Subasini, M., \& Kokilavani, B. (2013). Significance of grammar in technical English. International Journal of English Literature and Culture, 1(3), 5658.

Ushida, E. (2005). The role of students' attitudes and motivation in second language learning in online language courses. CALICO Journal, 23(1), 4978. 
LLT, e-ISSN 2579-9533, p-ISSN 1410-7201, Vol. 20, No. 2, October 2017

Veronica, A. C. S. (2008). Motivation in language learning. Economic Science Series, 17(1), 557-562.

Wang, F. (2010). The necessity of grammar teaching. English Language Teaching, 3(2), 78-90.

Weinstein, C. E., Mayer, R. E., \& Wittrock, M. C. (1986). The Teaching of Learning Strategies. In: Wittrock, M., Ed., Handbook of Research on Teaching. Macmillan: New York, 315-327.

Wigfield, A., \& Eccles, J. S. (1989). Test anxiety in elementary and secondary school students. Educational Psychologist, 24(2), 159-183.

Williams, M., \& Burden, R. (1997). Psychology for language teachers. Cambridge: Cambridge University Press.

Wolters, C. A. (2003). Regulation of motivation: Evaluating an underemphasized aspect of self-regulated learning. Educational psychologist, 38(4), 189-205.

Zhang, J. (2009). Necessity of grammar teaching. International Education Studies, 2(2), $184-187$.

Zimmerman, B. J. (1990). Self-regulated learning and academic achievement: An overview. Educational Psychologist, 25(1), 3-17.

Zumbrunn, S., Tadlock, J., \& Roberts, E. D. (2011). Encouraging self-regulated learning in the classroom: A review of the literature. Metropolitan Educational Research Consortium (MERC), 1-28. 